\title{
MIRROR THERAPY IN STROKE REHABILITATION
}

\author{
Lidwina S. Sengkey \\ Paola Pandeiroth
}

\author{
Bagian Ilmu Kedokteran Fisik dan Rehabilitasi \\ Fakultas Kedokteran Universitas Sam Ratulangi Manado \\ Email: lidwinasimasengkey@yahoo.co.id
}

\begin{abstract}
Paralysis in stroke is mainly caused by damage of any kind in internal capsule. Recovering of these damages require neuroplasticity which involves parts of the brain survivors. One kind of therapies that has some beneficial effects on neuroplasticity is mirror therapy. This therapy is used to improve motor function after stroke. Mirror therapy is easy to set up and requires very little training without taxing the patient. Data obtained from several studies show that besides it is simple and cheap, this mirror therapy might have a significant effect on motor function and improve activities of daily living as an adjunct to the rehabilitation for stroke patients. This review aims to demonstrate the benefits of mirror therapy in stroke rehabilitation.
\end{abstract}

Keywords: exercise therapy, mirror therapy, rehabilitation, stroke

\begin{abstract}
Abstrak: Paralisis pada stroke terutama terjadi karena kerusakan di kapsula interna. Kerusakan ini memerlukan neuroplastisitas yang melibatkan sejumlah bagian otak yang selamat untuk memulihkannya. Salah satu terapi yang bermanfaat terhadap neuroplastisitas yaitu terapi cermin. Terapi ini digunakan untuk memperbaiki fungsi motorik pasca stroke. Terapi cermin mudah dilakukan dan hanya membutuhkan latihan yang sangat singkat tanpa membebani pasien. Data yang diperoleh dari beberapa penelitian memperlihatkan bahwa terapi cermin merupakan terapi yang sederhana, murah, dan efektif dalam memperbaiki fungsi motorik (baik ekstremitas atas maupun bawah) dan aktivitas kehidupan sehari-hari, sebagai tambahan untuk rehabilitasi yang umumnya dilakukan pada pasien dengan stroke. Telaah ini bertujuan untuk menunjukkan keuntungan terapi cermin pada rehabilitasi stroke.
\end{abstract}

Kata kunci: terapi latihan, terapi cermin, rehabilitasi, stroke

Stroke is the leading cause of serious longterm disability in adults. More than $60 \%$ of stroke survivors suffer from persistent neurologic deficits that impair their activities of daily living. ${ }^{1}$ Paretic upper limb is a common and undesirable consequence of stroke that causes activity limitation. ${ }^{2}$ It has been reported that up to $85 \%$ of the stroke survivors experience hemiparesis and that $55-75 \%$ have continued limitations in functioning their upper extremities. ${ }^{2}$ After a stroke, lowerextremity motor function is often impaired, causing restrictions in functional mobility. ${ }^{2}$ Paralysis that follows a stroke is thought to be the result mainly of irreversible damages of the internal capsule. ${ }^{3}$

Traditionally, a physical therapy for a patient with hemiparesis in the weeks after a stroke consists of an exercise therapy based on neuromuscular re-education. It has been shown that functional organization of the motor system, including the primary motor cortex, can be modulated by both ipsilateral limb movements and passive observation of movements of the contra-lateral limb. ${ }^{4}$ Another alternative therapy is mirror therapy which was first introduced by Ramachandran and RogerRamachandran to treat phantom pain after 
an amputation. This therapy has been used to treat phantom limb pain in amputee patients, stroke patients, and etc. ${ }^{5}$

Although patients often regain some of their lost function after therapy, most remain chronically disabled. About $20 \%$ of these patients regain at least some part of their lost motor functions in the subsequent months; thus, 50-60\% are left with chronic motor disorders. These motor impairments may substantially compromise the quality of life after stroke. ${ }^{6}$ It seems that there is a relationship between the amount of sensory impairment and the degree of motor recovery.

Somato-sensory function contributes to performance of activities of daily living following the stroke. This somato-sensory loss is presents in more than $60 \%$ of people with strokes; therefore, it is important that rehabilitation interventions is aimed to the sensory as well as the motor impairments. ${ }^{6}$

\section{DEFINITION OF MIRROR THERAPY}

Mirror therapy is a relatively new therapeutic intervention that focuses on moving the unimpaired limb. It is a form of imagery in which a mirror is used to convey visual stimuli to the brain through observation of one's unaffected body part as it carries out a set of movements. ${ }^{4}$

\section{PROCEDURE OF MIRROR THERAPY}

The general procedures of mirror therapy is the patient sits in front of a mirror that is oriented parallel to his midline blocking the view of the affected limb which is positioned behind the mirror. While looking into the mirror, the patient sees the reflection of the unaffected limb positioned as the affected limb. This arrangement is suited to create a visual illusion whereby movement of or touch to the intact limb may be perceived as affecting the paretic limb. After that, the patient involves performing movements of the unimpaired limb while watching its mirror reflection superimposed over the (unseen) impaired limb. ${ }^{7}$

\section{Mirror therapy for the upper extremity}

The stroke survivor is seated and a mirror is aligned to intersect with the patient's body in the sagittal plane at chest level. This is usually done by placing the mirror on the table with the hands resting on the table on either side of the mirror. The reflective part of the mirror faces the unaffected side. As the patient looks into the mirror, all they see is the unaffected side. The mirror blocks the view of the unaffected side of the body. The patient gazes into the mirror reflecting the "good" hand. When the "good" hand is moved the mirror gives the illusion that the "bad" hand is moving perfectly well. The stroke survivor attempts to copy the movement of the "good" arm and hand to the hemiparetic arm. Although the stroke survivor only sees the reflection of the good hand, the movements look symmetrically (Fig. 1). ${ }^{8}$

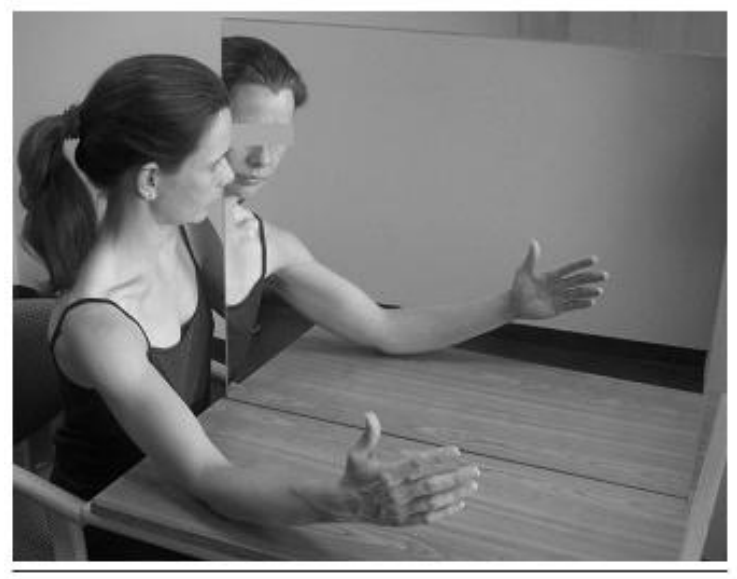

Figure 1. The patient's affected arm is hidden behind the mirror. While moving her unaffected arm, the patient watches its mirror image as if it is the affected one. Source: Dohle C et al., 2009. ${ }^{9}$

\section{Mirror therapy for the lower extremity}

The stroke survivor can be either in long sitting on a plinth or seated on a chair. The advantage of the plinth is that the lower extremity is more easily viewed. The advantage of the chair is that it may be more comfortable for some patients. In either case, a mirror is placed between the 
patient's legs to intersect his/her body in the sagittal plane facing the unaffected side. The patient is instructed to do plantar and dorsiflexion of the unaffected side ankle, and at the same time attempting to do the same movement with the affected side. The speed of the movement is self-selected. For both upper and lower extremities the dosage is 30 minutes a day, and 5 days a week for 4 weeks. $^{8}$

\section{MECHANISM OF MIRROR THERAPY}

The concept of mirror therapy has been further substantiated neurophysiologically. An imaging experiment demonstrated that inversion of the visual image of a hand can elicit lateralized cortical activetion. In other words, when a right hand is used, but perceived as a left hand, this leads to an additional activation of the right hemisphere (and vice versa). The mirror provides patients with proper visual input the mirror reflection of the moving good arm looks like the affected arm moving correctly- and perhaps substitutes for the decreased or absent proprioceptive input. ${ }^{9}$

Mental images of movement can be generated independently of overt behavioral output of a paretic limb. Humans are equipped with a simulation network that positions the motor system in anticipation of movement execution and provides themselves with information about the possibility and meaning of up coming actions. The processes underlying motor imagery are similar to those that are active during actual movement. Actions generated by using motor imagery adhere to the same rules and constraints that physical movements follow. The neural network involved in motor imagery and in motor execution overlap each other, primarily in the premotor and parietal areas, basal ganglia, and cerebellum. ${ }^{10}$

The use of a mirror may recruit the premotor cortex to motor rehabilitation. ${ }^{11}$ The premotor cortex has a number of features suggesting that it might possibly be a link from the visual image in the mirror to motor rehabilitation after stroke as follows: non-trivial contributions to the descending corticospinal tracts; more bilateral control of movement than the motor cortex itself; and intimate connection between premotor areas and visual input. ${ }^{12}$ As well as a number of neurological and psychological levels, mirror therapy may help to reverse elements to the disused affected limb. ${ }^{10}$

The role of mirror therapy in influencing sensory impairments is still unclear. It might be caused by the visual input provided by the reflection of the mirroris combined with the altered or absent sensation of the paretic hand via the corpus callosum or via the activation of mirror neurons. ${ }^{5,13}$

Another explanation is the advantage of mirror neurons discovered by Rizzolatti et al. in the early 1990s. ${ }^{12}$ These neurons are found in the frontal lobes as well as the parietal lobes. These areas are rich in motor command neurons. Each of which fires to orchestrate a sequence of muscle twitches to produce simple skilled movement such as: reaching a peanut, pushing a stone, or putting an apple in to the mouth. A subset of these mirror neurons also fire when the person merely watches another individual performing the same movement. Mirror neurons necessarily involve interactions among multiple modalities (vision, motor commands, and proprioception) which suggest that they might be involved in the efficacy of mirror therapy in stroke. ${ }^{3}$

Stroke paralysis results partly from actual permanent damages in the internal capsule. An additional possibility is that lesion is not always complete; there may be a residue of mirror neurons that have survived but are dormant or their activity is inhibited and does not reach the threshold. So, mirror therapy might owe part of its efficacy to stimulates these neurons, thus providing the visual input to revive the motor neurons. ${ }^{3}$

\section{RESULTS OF STUDIES IN MIRROR THERAPY}

Dohle et al. ${ }^{9}$ evaluated the effect of a therapy that included the use of a mirror to 
simulate the affected upper extremity with the unaffected upper extremity early after stroke. There were 36 patients with severe hemiparesis caused by the first-ever ischemic stroke in the territory of the middle cerebral artery not more than 8 weeks after the stroke. They completed a protocol of 6 weeks of additional therapy (30 minutes a day, 5 days a week) with random assignment to either mirror therapy or an equivalent control therapy. The main outcome measures were the Fugl-Meyer subscores for the upper extremity, evaluated by independent raters through videotapes. Patients also underwent functional and neuropsychological tests. This study showed that at the beginning of the therapy in the subgroup of 25 patients with distal plegia, mirror therapy patients regained more distal function than control therapy patients. Furthermore, across all patients, mirror therapy improved recovery of surface sensibility. Neither of these effects depended on the side of the lesioned hemisphere. It is concluded that mirror therapy early after stroke was a promising method to improve sensory and attentional deficits, and to support motor recovery in a distal plegic limb.

According to Stevens and Stoykov ${ }^{10}$ in rehabilitation for hemiparesis, one of the goals of an occupational therapist was to practice upper extremity tasks with the recovering individual. The practice was intended to strengthen muscles and refine movements. It also provided examples for the recovering body and brain as they attempted to re-establish their delicate cognitive and neural connections mediating voluntary behavior. They outlined a method for simulation of movement by using a mirror. The simulation provided a compelling perceptual experience of bilateral motion beyond the current capabilities of the affected limb. A 3-week course of the simulation practice revealed improved function as demon-strated by increases in Fugl-Meyer scores and faster movement speeds as demon-strated by decreased movement times for the Jebsen test of hand function. ${ }^{14}$
Yavuzer et al. $^{2}$ evaluated the effects of mirror therapy on upper-extremity motor recovery, spasticity, and handrelated functioning of inpatients with subacute stroke. Their study design was randomized, controlled, assessor-blinded, 4-week trial, with follow-up at 6 months. There were a total of 40 inpatients with stroke (mean age 63.2 years), all within 12 months post stroke. The intervention they did was 30 minutes of mirror therapy program a day consisting of wrist and finger flexion and extension movements or sham therapy in addition to conventional stroke rehabilitation program, 5 days a week, 2 to 5 hours a day, for 4 weeks. The measurement of outcome was conducted by the Brunnstrom stages of motor recovery, spasticity assessed by the Modified Ashworth Scale (MAS) and hand-related functioning (self-care items of the Functional Independence Measure (FIM) instrument). The results showed that the scores of the Brunnstrom stages for the hand and upper extremity and the score of FIM self-care improved more in the mirror group than in the control group after 4 weeks of treatment $(P<.01)$ and at the 6-month follow-up $(P<.05)$. No significant differences were found between the groups for the MAS. It was concluded that in the group of subacute stroke patients, hand functioning improved better after mirror therapy in addition to a conventional rehabilitation program compared with a control treatment immediately after 4 weeks of treatment and at the 6-month follow-up, whereas mirror therapy did not affect spasticity. ${ }^{2}$

Kuys et al. ${ }^{15}$ studied the effects and adherence of mirror therapy among people with chronic upper limb hemi-paresis. Participants of 12 people with chronic hemiparesis underwent a 30-minutesensorimotor mirror therapy home-based exercise program 3 times a week for 6 weeks. The compliance with the program and the effect on sensory outcomes were determined. Light touch threshold and proprioceptive error, upper limb activity limitations, and participation restrictions 
were measured at baseline (week 0 ), immediately after week 6 , and 6 weeks following the intervention (week 12). Compliance with the program was fair, and $66 \%$ of supervised and $62 \%$ of unsupervised sessions were completed. The paretic hand performed worse compared to nonparetic hand at baseline with no difference in sensory measures demonstrated over time. Activity limitations and participation restrictions improved by week 12 ( $P$ $<0.05)$. This sensorimotor mirror therapy home-based exercise program showed little improvement in light touch threshold and proprioception that appeared to be functionally important for this group of people with chronic hemiparesis. Mirror therapy may be a useful tool for clinicians, particularly for patient with independent use.

Youn et al. ${ }^{16}$ carried on a study to delineate the changes in corticospinal excitability when individuals were asked to exercise their upper extremity using a real mirror and virtual mirror (Fig. 2). Moreover, they attempted to delineate the role of visual modulation within the virtual environment that affected corticospinal excitability in healthy subjects and stroke patients.

There were a total of 18 healthy subjects and 18 hemiplegic patients enrolled in their study. Motor evoked potential (MEPs) from transcranial magnetic stimulation were recorded in the flexor carpiradialis of then on dominant or affected upper extremity using three different conditions: 1) relaxation; 2) real mirror; and 3) virtual mirror. Moreover, they compared the MEPs from the virtual mirror paradigm using continuous visual feedback or intermittent visual feedback. The result stated that the rates of amplitude increment and latency decrement of MEPs in both groups were higher during the virtual mirror task than during the real mirror. In healthy subjects and stroke patients, the virtual mirror task with intermittent visual feedback significantly facilitated corticospinal excitability of MEPs compared with continuous visual feedback. ${ }^{16}$

\section{OUR EXPERIENCE IN MIRROR THERAPY}

Sengkey and Pandeiroth (2008) studied the comparison between exercise therapy and exercise therapy with mirror on the lower limb functional motoric recovery in post stroke patients $\leq 1$ year in Prof. Dr. R.D. Kandou General Hospital (Figure 3). This was a quasi experimental study with a pretest and posttest control group design. There were 24 patients aged 40-65 years who received 15 minutes exercise therapy sessions 3 times a week for 4 weeks. Randomly, 12 patients were assigned for the exercise therapy and the other 12 patients for exercise therapy with mirror.
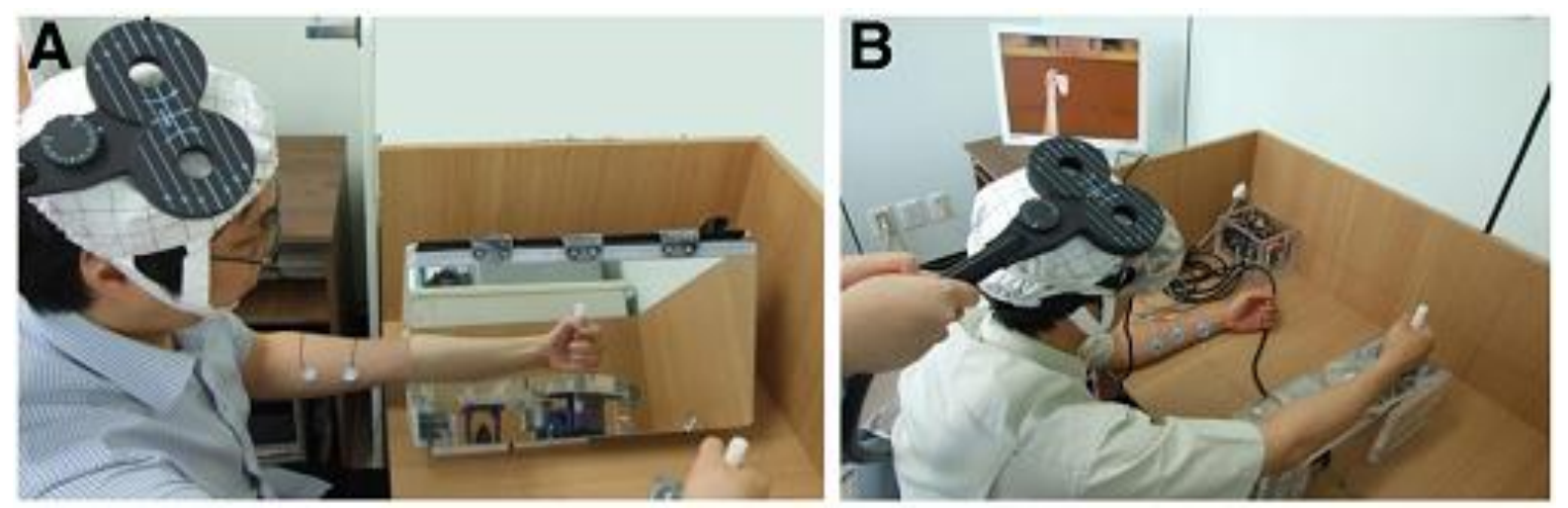

Figure 2. Setup of the real mirror (A) and virtual mirror (B) experiments. Source: Youn JK, et al., $2012 .^{16}$ 


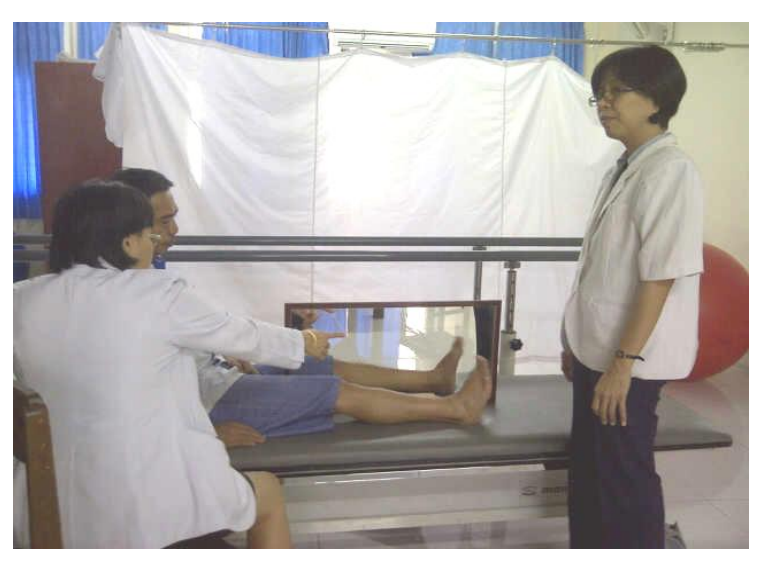

Figure 3. Mirror therapy on the inferior extremity of a male patient with stroke at Rehabilitation Department Prof. Dr. R.D. Kandou General Hospital.

The lower limb motoric recovery was assesed by using the Brunnstrom Stages before and after exercise (tested by Wilcoxon signed ranks). There was a significant increase of the Brunnstrom Stages $(P<0.01)$. Moreover, the Brunnstrom Stages that were tested by using paired $\mathrm{T}$ test before and after exercise therapy with mirror also stated a significant increase $(P$ $<0.01)$. The Mann-Whitney $U$ test for the Brunnstrom stages of these two groups showed that the mean rank of exercise group was 10.0 while of mirror therapy group 15.0 with $P<0.05$. This indicated that the exercise therapy with mirror was better than the exercise therapy alone.

For Functional Independence Measure (FIM), the score of motoric before and after given exercise therapy increased from 43,0 to 54,5 which mentioned a significant recovery of motoric functional $(P<0,01)$. For exercise therapy with mirror, the score of FIM before and after mirror therapy increasing from averagely 63,3 to 75,3 . These results showed that the functional recovery produced by both therapies were significant, but the FIMs of both groups were not different significantly $(P>0.05)$. It is concluded that exercise therapy with mirror may improve lower limb functional recovery in post stroke patients.

\section{CONCLUSION}

Mirror therapy is an alternative therapeutic intervention that focuses on moving the unaffected limb to convey visual stimuli to the brain through observation of those movements in a mirror. This observation may recruit the premotor cortex to motor rehabilitation of the affected parts of the brain.

Studies showed promising results of this therapy in improving sensory and motor function following stroke.

Mirror therapy is an alternative therapeutic intervention that focuses on moving the unaffected limb by using a mirror to convey visual stimuli to the brain through observation of one's unaffected body part as it carries out a set of movements. The use of a mirror may recruit the premotor cortex to motor rehabilitation. Studies showed a promising results of mirror therapy by improving sensory and motor function following stroke.

\section{REFERENCES}

1. Hummel F, Celnik P, Giraux P, Floel A, Wu W, Gerloff C, et al. Effects of non-invasive cortical stimulation on skilled motor function in chronic stroke. Brain. 2005;128:490-9.

2. Yavuzer G, Selles R, Sezer N, Sutbeyaz S, Bussmann JB, et al. Mirror therapy improves hand function in subacute stroke: a randomized controlled trial. Arch Phys Med Rehabil. 2008;89:393-8.

3. Ramachandran VS, Altschuler EL. The use of visual feedback, in particular mirror visual feedback, in restoring brain function. Brain. 2009;132:16931710.

4. Sütbeyaz S, Yavuzer G, Sezer N, Koseoglu F. Mirror therapy enhances LowerExtremity Motor Recovery and Motor Functioning After Stroke: A Randomized Controlled Trial. Arch Phys Med Rehabil. 2007;88:555-9.

5. Ramachandran VS, Rogers-Ramachandran D. Synaesthesia in Phantom Limbs Induced with Mirrors. Proceedings: Biological Sciences. 1996;263:377-86. 
6. Hendricks HT, van Limbeek J, Geurts AC, Zwarts MJ. Motor recovery after stroke: a systematic review of the literature. Arch Phys Med Rehabil. 2002;83:1629-37.

7. Rothgangel AS, Braun SM, Seitz RJ, Wade DT. The clinical aspects of mirror therapy in rehabilitation: a systematic review of the literature. International Journal of Rehabilitation Research. 2011;34:1-13.

8. Levine $P$. Not just smoke and mirrors [homepage on the Internet]. 2010 [cited 2013 Aug 16]. Available from: http://physicaltherapy.advanceweb.com /Columns/From-the-Lab/Not-JustSmoke-and-Mirrors.aspx

9. Dohle C, Pullen J, Nakaten A, Kust J, Rietz C, Karbe H. Mirror therapy promotes recovery from severe hemiparesis: a randomized controlled trial. Neurorehabil Neural Repair. 2009,23:209-17.

10. Stevens JA, Stoykov ME. Using motor imagery in the rehabilitation of hemiparesis. Arch Phys Med Rehabil. 2003;84:1090-2.

11. Seitz RJ, Hoflich O, Binkofski F, Tellmann L, Herzog H, Freud HJ. Role of the premotor cortex in re- covery from middle cerebral artery infarction. Arch Neurol. 1998;55:1081-8.

12. Pellegrino G, Fadiga L, Fogassi L, Gallese V, Rizzolatti G. Understanding motor events: a neurolophysiological study. Brain. 1992;91:176-80.

13. Franz EA, Packman T. Fooling the brain into thinking it sees both hands moving enhances bimanual spatial coupling. Experimental Brain Research 2004; 157:174-180.

14. Stevens JA, Stoykov ME. Simulation of bilateral movement training through mirror reflection: A case report demonstrating an occupational therapy technique for hemiparesis. Top Stroke Rehabil. 2004;11(1):59-66.

15. Kuys SS, Edwards T, Morris NR. Effects and Adherence of Mirror Therapy in People with Chronic Upper Limb Hemiparesis: A Preliminary Study. International Scholarly Research Network 2012.

16. Youn JK, Hae KP, Hyun JK, Soo JI, Jeunghun K, Sangwoo C, et al. Upper extremity rehabilitation of stroke: Facilitation of corticospinal excitability using virtual mirror paradigm. Journal of NeuroEngineering and Rehabilitation. 2012;9:71. 